\title{
ГЕОПОЛИТИЧЕСКИЕ ПРОБЛЕМЫ АРКТИКИ*
}

\author{
(C) 2013 г. Т.И. Горкина
}

Институт географии РАН

Поступила в редакцию 14.12.2012 г.

\begin{abstract}
Рассматриваются проблемы международного сотрудничества и противостояния арктических го-
\end{abstract} сударств по вопросу делимитации границ и будущего использования арктического пространства.

На рубеже XX-XXI вв. во всем мире резко возрос интерес к Арктике, которую благодаря ее циркумполярному положению между Евразией и Северной Америкой все чаще стали называть “Новым Средиземноморьем”. Такое географическое положение является качественной характеристикой арктического пространства, которая в случае потепления климата повысит его ценность не только за счет добычи полезных ископаемых, но и благодаря созданию в нем кроссполярных маршрутов и транспортных коридоров по оси Запад - Восток. Пространственный фактор оказывает большое влияние на принятие решений в арктической политике, в частности, таких как делимитация границ и определение интернациональных зон.

Пристальное внимание к Арктике, которую часто называют последней на планете крупной кладовой минеральных ресурсов, вызвано тем, что скорость потепления здесь в 2 раза выше среднемировой. В последние 20 лет наблюдается заметное сокращение площади льда, которая уменьшилась с 1978 г. на 8\%, а температура верхнего слоя вечной мерзлоты повысилась на $3^{\circ}$. Многие западные эксперты прогнозируют, что к 2099 г. при сохранении тенденции к потеплению возможно полное освобождение океана от льда в летнее время. Российские НИИ Арктики и Антарктики и другие научные институты дают более осторожные оценки, так как тенденция к потеплению не столь однозначна - с 2008 г. наметился тренд к похолоданию. К такому же выводу пришли и американские исследователи, по мнению которых ближайший скачок в сторону похолодания произойдет приблизительно через 10 лет.

\footnotetext{
* Исследование выполнено в рамках Программы фундаментальных исследований Президиума РАН № 31 "Роль пространства в модернизации России: природный и социально-экономический потенциал”.
}

Анализ долгосрочных наблюдений говорит о том, что в Арктике всегда наблюдалась цикличность в таянии и увеличении морских льдов.

Тем не менее, именно потепление климата повысило геополитическую значимость Арктики, поскольку это способствует большей доступности данного региона, что создает напряженность между арктическими странами по вопросам раздела акватории и континентального шельфа.

Более активное вхождение Арктики в мировое хозяйство возможно по следующим причинам. Во-первых, здесь сосредоточены огромные энергетические ресурсы, необходимые в будущем для всего человечества. По некоторым оценкам, это не менее 10 млрд т нефти и 5 млрд т газового конденсата, почти 50 трлн куб. м природного газа. При этом надо учитывать недостаточное изучение ряда районов Арктики, особенно в восточной части российского сектора. В 2008 г. Геологическая служба США сообщила, что на Арктику приходится 13\% мировых неразведанных ресурсов нефти и $30 \%$ природного газа [8]. Северный Ледовитый океан более чем в 5 раз богат углеводородами, чем Тихий, в 1.8 раз - чем Атлантический, в 1.5 раз чем Индийский океан. Во-вторых, Арктика богата редкими и редкоземельными металлами, минералами, рудами и другим сырьем, имеющим стратегическое значение. В-третьих, здесь сосредоточены биологические ресурсы общемирового значения. Это ареал существования многих уникальных видов животных и рыб. В-четвертых, Арктика оказывает огромное влияние на климат планеты и состояние природной среды. В-пятых, предполагается создание так называемого Арктического моста между континентами, состоящего из морских и авиационных трасс, частью которого станут российский Северный морской путь (СМП) и канадский Северо-Западный проход. Этот маршрут будет иметь геополитическое 
Таблица 1. Удельный вес Арктики в добыче энергетического и минерального сырья в мире, \%

\begin{tabular}{|l|l|l|}
\hline Нефть 10.5 & Титан 0.3 & Золото 3.2 \\
\hline Природный газ 25.5 & Вольфрам 9.2 & Серебро 3.6 \\
\hline Уголь 2.1 & Бокситы 1.9 & $\begin{array}{l}\text { Алмазы ювелир- } \\
\text { ные 26.8 }\end{array}$ \\
\hline Железная руда 2.3 & Цинк 7.8 & $\begin{array}{l}\text { Алмазы техниче- } \\
\text { ские 23.3 }\end{array}$ \\
\hline Никель 10.6 & Свинец 5.6 & Фосфаты 3.7 \\
\hline Кобальт 11.0 & Медь 3.8 & Вермикулит 5.8 \\
\hline Хромиты 4.2 & $\begin{array}{l}\text { Палладиум } \\
40.0\end{array}$ & \\
\hline
\end{tabular}

Источник: [14]

значение, так как станет альтернативой южным транспортным коридорам, имеющим высокую загруженность и проходящим часто через политически нестабильные районы. В-шестых, большое значение для всех государств, причем не только арктических, имеет военная составляющая, которую желательно рассматривать не как прямую военную угрозу, а с точки зрения коллективной безопасности. В-седьмых, важная задача - сохранение и адаптация к современным условиям хозяйствования коренных жителей, представителей древнейшей циркумполярной цивилизации.

Эти проблемы лежат в основе геополитики, проводимой в Арктической зоне (АЗ) прежде всего арктическими странами для получения конкурентных преимуществ в ее освоении. Реализация государственных проектов здесь затруднена серьезными обстоятельствами политического, экономического и экологического свойства. Несмотря на ограниченное экономическое и социальное развитие арктических регионов, они занимают определенную нишу в мировой добывающей промышленности, о чем свидетельствуют данные табл. 1. Особенно большой вклад в мировое производство редкоземельных металлов вносит Россия, которая является единственной страной среди арктических государств с развитой горнодобывающей и топливной промышленностью, работающей на Севере не по принципу вахтового метода, а на основе постоянно обитаемых населенных пунктов. Оценочная стоимость ресурсов минерального сырья только в российской Арктике составляет более 30 трлн долл., 2/3 из которых приходится на углеводороды.

Арктика мало исследована, во многих районах геологоразведочные работы (ГРР) не проводились совсем. Тем не менее, отступление льдов позволило интенсифицировать ГРР на значительных территориях. Все государства, которым принад- лежат высокоширотные регионы Арктики, активизируют их прежде всего в поисках нефтегазовых ресурсов. В результате этих работ на шельфе было открыто много новых месторождений, в том числе 42 месторождения в Канаде, 35 - в Норвегии, 23 - в России, 22 - на Аляске.

Во многих арктических районах Западного полушария ведутся сейчас ГРР, в частности в северо-восточной части Гренландии. Активизируют ГРР на полярных участках корпорации "ConocoPhillips", "Statoil" и "Royal Duth/Shell". Однако авария на буровой платформе компании "British Petroleum" в Мексиканском заливе повлияла на проведение работ в арктической зоне. Под давлением общественности США и Канада практически полностью заморозили буровые работы в своих секторах Арктики.

По оценке Министерства природных ресурсов и экологии РФ углеводородный потенциал шельфа нашей страны - самого протяженного среди всех арктических государств - составляет приблизительно 100 млрд т, распределенных по 16 крупным морским нефтегазовым провинциям и бассейнам. Основная часть приходится на наиболее изученные шельфы Баренцева, Карского и Печорского морей. Министерство выделило в Арктике три кластера по степени изученности недр. Первый кластер - Баренцево-Печорский, где уже идет процесс лицензирования. В перспективе возможны новые открытия. Этот кластер обладает таким преимуществом, как близость к европейскому энергетическому рынку. Ледовые условия здесь не очень сложные, что способствует развертыванию добычи в этом регионе. Второй кластер - Карско-Ямальский: его степень изученности низкая, но на суше хорошо развита инфраструктура для газовой промышленности. Ледовые условия здесь от умеренно до весьма сложных. Перспективы разработки достаточно высокие в расчете на экспорт как на европейские, так и на рынки Азиатско-Тихоокеанского региона. Третий кластер - Восточно-Сибирский. Он имеет очень сложные природно-климатические условия, а также крайне низкую степень изученности недр и практически полное отсутствие какой-либо инфраструктуры. Он может стать интересным для инвесторов в очень отдаленной перспективе как поставщик углеводородов для Дальнего Востока, Восточной Сибири и Азиатско-Тихоокеанского региона [4].

В силу своего географического положения и благодаря наличию большого числа полезных ископаемых, в первую очередь нефти и газа, Арктика стала особым регионом, где пересекаются 
геополитические и экономические интересы не только арктических и приарктических государств, но и других стран, которые считают Арктику достоянием всего человечества. Поэтому освоение АЗ должно проводиться на основе международного сотрудничества и частно-государственного партнерства, консолидации действий на национальном и международном уровнях для сбалансированного развития системы "человек - социум - природная среда".

Международное сотрудничество. Международное сотрудничество стало особенно заметно с начала 1990-х гг., когда началась совместная работа разных государств по выработке общей стратегии в Арктике. Особенно активно оно проявляется в научных исследованиях и мониторинге природной среды. В этой работе участвует большое число различных организаций, важнейшими из которых являются: Арктический совет, Совет Баренцева/Евроарктического региона (СБЕР), Евросоюз и НАТО.

Очень велика роль этих организаций в стабилизации и поддержании равновесия между арктическими странами. Арктический Совет, созданный в 1991 г. для защиты уникальной природы A3, решает важные вопросы в области охраны окружающей среды, осуществляет в Арктике также социально-экономический мониторинг. Благодаря его работе в 2011 г. было подписано Соглашение о предотвращении разливов нефти и обеспечении безопасности и спасения в авиации и на морском транспорте. Арктический Совет занимается также управлением биологическими ресурсами, образованием, НИОКР, проводит изучение и мониторинг перспектив и последствий потепления.

В СБЕР, созданном в 1993 г., решения принимаются на уровне министров иностранных дел. Его деятельность направлена на реализацию проектов по устойчивому развитию региона на основе международного сотрудничества. В рамках этой организации Россия сотрудничает с НАТО, что очень важно с геополитической точки зрения. Рабочие группы СБЕР разрабатывают программы по всем важным траекториям развития региона - экономике, энергетике, экологии и др. СБЕР предлагает внедрить в АЗ режим международного управления по типу антарктического. Для этого, как предполагает СБЕР, не нужно создавать новый орган, достаточно лишь преобразовать Арктический совет в межправительственную организацию с международными функциями управления.

Программы Европейского Союза по использованию АЗ носят прагматичный характер. Все страны-члены ЕС приняли специальный Арктический договор о хозяйственном использовании Арктики, против него выступили только европейские экологи, которые считают, что этот регион должен получить статус всемирного заповедника по примеру Антарктики, где могут проводиться только научно-исследовательские работы. ЕС это не поддерживает, а, наоборот, в рамках программы “Северное измерение", инициированной Финляндией, в партнерстве с Россией и с привлечением финансовых ресурсов ЕС разрабатывает программы в области транспорта, экологии, здравоохранения и культуры. Для этих целей Европейское космическое агентство готовит запуск спутника для работы на полярной орбите для более эффективного мониторинга за морским судоходством и рыболовством. ЕС считает, что Арктический Совет должен стать головной политической организацией по вопросам сотрудничества в АЗ при расширении его сферы деятельности и компетентности [15].

На саммите в Исландии в 2009 г. НАТО признала наличие у нее стратегических интересов в АЗ. Был представлен доклад "Многочисленные угрозы в будущем” о новой стратегии альянса на ближайшие 25 лет. Наиболее актуальными были признаны проблемы изменения климата и обострение борьбы за доступ в АЗ [2]. Генеральный секретарь НАТО Расмуссен Андерс Фог считает, что безопасность в АЗ станет ключевым вопросом новой стратегии НАТО при активном сотрудничестве с Россией.

По мнению министра иностранных дел РФ С. Лаврова, НАТО не должна вмешиваться в дела Арктического Совета и др. организаций, так как АЗ - это зона экономических интересов. Однако НАТО в рамках арктической “восьмерки”, пять стран которой - члены НАТО, уже сотрудничает с РФ в этом Совете. Примером этого может служить подписание "Соглашения о сотрудничестве в авиации и морском поиске и спасении в Арктике”. В национальных арктических программах северных стран также говорится о необходимости сотрудничества с Россией и декларируется намерение обеспечивать собственные интересы в Арктике в случае конфликтов с помощью национальных вооруженных сил, а не блока НАТО.

В России, на долю которой приходится треть арктической зоны, разработана "Дорожная карта”, определяющая последовательные шаги взаимодействия РФ с зарубежными государствами и международными организациями по актуальным вопросам политики в Арктике на 2012-2018 гг. Она включает различные аспекты международ- 
ного сотрудничества: правовые, институциональные, транспортные, природно-ресурсные, экологические, военные, научно-исследовательские. РФ выступила с инициативой проведения международного полярного десятилетия 2015-2025 гг., подобного полярному году 2007-2008 гг.

Особенно активно международное сотрудничество осуществляется в научно-исследовательской области. Приведем несколько примеров. Одним из крупных проектов российско-американского сотрудничества стало создание в Тикси международной комплексной исследовательской обсерватории на базе метеостанции "Полярка", открытой в 1932 г. В ее работе примут участие Росгидромет и РАН, Национальный научный фонд США, финский Метеорологический институт, а также ряд научно-исследовательских организаций других стран. Обсерватория в Тикси станет важным компонентом сети действующих арктических обсерваторий, состоящей из следующих обсерваторий: Барроу на Аляске, Еурика и Алерт в Канаде, Абиско в Швеции, Саммит в Гренландии, норвежской Ну-Алесунд и финских Паллас и Соданкула. В целом работа этих обсерваторий обеспечит циркумполярный мониторинг гидрологических и метеорологических процессов в высоких широ$\operatorname{Tax}[17]$.

Очень успешно в рамках международного сотрудничества работает НИИ Арктики и Антарктики, где созданы российско-немецкая лаборатория морских и полярных исследований им. О.Ю. Шмидта и российско-норвежская лаборатория исследования климата Арктики им. Фрама, которые получают гранты от Евросоюза, Норвегии и Германии.

Центр навигационных исследований в г. Варде (Норвегия) играет ключевую роль в российсконорвежском сотрудничестве по вопросам безопасности мореплавания и разработки сценариев борьбы с разливами нефти. В 2000-х гг. в Мурманской области работала российско-шведская группа по гуманитарным аспектам проблемы губы Андреева, где размещаются предприятия СевРАО: радиоэкологической безопасности, утилизации атомных подводных лодок, обращении с радиоактивными отходами и отработанным ядерным топливом. ЕС выделил 1.3 млн евро на создание с участием специалистов из Нидерландов информационного центра на атомном ледоколе “Ленин”. Центр получает информацию обо всех радиационных объектах Мурманской области и распространяет эти сведения в Северной Европе.

По инициативе СБЕР в Арктическом регионе по программе "Баренц Рескью" проводятся трансграничные учения (раз в два года) по очереди в каждой из стран бассейна Баренцева моря: 2001 г. - Швеция, 2005 г. - Норвегия, 2007 г. Финляндия, 2009 г. - Россия (Мурманская область), 2011 г. - Швеция. Как правило, во время учений отрабатывается несколько сценариев, в том числе разлив нефти и радиоактивное загрязнение. Как правило, в учениях участвуют более 2 тыс. спасателей.

Успешный опыт международного сотрудничества в научной сфере поможет в будущем и в совместной работе в нефтегазовой сфере. Для России международное сотрудничество началось с разработки проекта Штокмановского месторождения, участниками которого стали "Газпром", “Тоталь" и "Статойл". В 2011 г. Роснефть образовала альянс с “ЭксонМобил” с целью создания совместных предприятий для проведения работ на Карском море, на осуществление которых компания направляет 300 млрд долл. В свою очередь Роснефть приобрела доли в трех проектах “ЭксонМобил” в США и Канаде. Участие иностранных компаний в разработке арктических проектов очень важно, так как они не только инвестируют, но и разделяют риски, поскольку не все проекты могут быть осуществлены после проведения ГРР. Например, британская "Cairn Energy" в надежде обнаружить ресурсы углеводородов на шельфе Гренландии потеряла 750 млн евро.

В изучении и освоении Арктики велика роль Норвегии, которая имеет наиболее передовые технологии для работы в северных условиях. В 2011 г. парламенту Норвегии был представлен доклад "Северные регионы - картины будущего и методы претворения их в жизнь”, основным тезисом которого стало устойчивое управление ресурсами на основе международного сотрудничества, что является решающим фактором для всей деятельности на Севере. Одним из ведущих центров по изучению Арктики в Норвегии стал г. Тромсё. Здесь в январе 2012 г. прошла VI Международная конференция "Арктические рубежи”, главными темами которой стали оценка ресурсного потенциала Арктики, влияние на региональную политику изменений на мировых рынках энергии, возможности использования возобновляемой энергии и экологически безопасных технологий.

В Арктике нет международной системы принятия решений для получения интегрального результата. Для комплексного развития нужна разработка единой программы действий для всех природопользователей. В основе такой программы должна лежать экологическая политика со 
схемой комплексного интегрированного управления: морское природопользование - развитие аквакультур - рыболовство - судоходство - добыча углеводородов - туризм. Пока для такого взаимодействия действует ряд международно-правовых документов, касающихся в основном добычи нефти и газа.

Примером комплексного интегрированного управления может стать создание так называемого Арктического моста, в зону влияния которого войдут не только Россия и Канада, но и другие страны Арктики. Программа такого управления была рассмотрена на конференции "Breaking Ice" в 2007 г. в Исландии. Ключевым портом должен стать Мурманск, замыкающий на себе СМП и трассы из Гудзонова залива до Мурманска. Таким образом, будет создан трансарктический маршрут от Берингова моря до Дублина протяженностью 2.1 тыс. морских миль, что на 40\% короче южного маршрута от Атлантического до Тихого океана.

При транспортировке через такой протяженный маршрут понадобятся порты для перевалки грузов. В частности, для этих целей подходит Исландия, которая ежегодно принимает до 250 нефтяных и СПГ-танкеров. Предполагается, что к 2015 г. их количество удвоится [11]. Большие надежды на эту программу возлагает также Ирландия, которая планирует построить новый глубоководный порт в устье р. Шеннон, и возродить производство на верфи в Белфасте, где будут строиться атомные ледоходы. Россия предполагает не только создать новые порты, но и задействовать более активно уже существующие, расположенные на арктическом побережье и Белом море.

В СССР в 1980-е гг. по СМП перевозилось до 20 млн т/г. После распада СССР его грузооборот упал с 6.7 млн т в конце 1980-х гг. до 1.4 млн т в 1998 г. С начала 2000-х гг. ситуация стала меняться, грузооборот на СМП возрос в основном за счет каботажных и, частично, экспортных перевозок. В настоящее время его потенциал используется в среднем на $30 \%$, но возможно, что рост произойдет в обозримой перспективе за счет международных перевозок, которые законодательно были разрешены еще в 1991 г., но пользоваться этим маршрутом стали более активно только с 2010 г. прежде всего немецкие и норвежские экспортеры. По подсчетам иностранных компаний экономия от перевозок по СМП по сравнению с транспортировкой через Суэц составляет порядка 300 тыс. евро для каждого судна.

Для функционирования Арктического моста потребуется создание новых портовых условий и технологий, а также увеличение числа судов ледового класса, в том числе и новых ледоколов. Особенно это касается России, так как трассы СМП пролегают в пределах ее экономической зоны. Наличие такой коммуникации делают АЗ регионом особого значения с точки зрения долгосрочного развития экономики РФ с учетом роста экспорта из ее арктического сектора, поскольку СМП связывает между собой российские регионы. Предполагается, что СМП сможет взять на себя 10-15\% грузооборота между Азией и Европой.

Для обеспечения перевозок по СМП до 2015 г. в РФ есть шесть ледоколов, срок службы которых истечет к 2015-2022 гг. К 2020 г. в действии останутся только два - “Ямал" и “50 лет Победы". Предусматривается, что к 2020 г. в состав ледокольного флота РФ войдут три ледокола нового типа, которые смогут заменить пять существующих [10]. Новые ледоколы для России и других арктических стран уже строятся в Финляндии. Кроме этого, в рамках Арктической стратегии Россия совместно с Финляндией приступили к формированию нового судостроительного кластера с базой в Кронштадте. На о. Котлин фирмы из Финляндии и южнокорейская компания "STX" планируют возвести "Ново-Адмиралтейские верфи”, где будут строиться крупные суда, в том числе и газовозы для арктических месторождений. Осуществление этих планов будет способствовать промышленному международному сотрудничеству.

В РФ большое внимание уделяется северным районам, где сосредоточено 16\% полезных ископаемых мира. В северных районах нашей страны находится 30 городов с населением более 10 тыс. чел. в каждом, среди них выделяется Мурманск с населением около 500 тыс. жителей. Для сравнения приведем такие примеры. В Северной Америке на Аляске проживает 630 тыс. жителей, а в самом крупном канадском поселке Инувик насчитывается порядка 3 тыс. человек. В зоне влияния СМП должны быть построены новые города с применением технологий, используемых на международной космической станции для создания умеренного климата и с учетом канадского опыта строительства в северных районах [12].

Все более активное использование арктических территорий увеличивает экологические риски, поэтому так важно международное сотрудничество, действующее в рамках принятых соглашений. Экологическое загрязнение в регионе усилилось с 1970-х гг. Особенно это характерно для российского Севера с его постоянными пунктами проживания. Наиболее пострадали побережья 
Баренцева и Карского морей, на которые оказали негативное влияние как военные (ядерные испытания на Новой Земле, базы ВМФ Северного флота и др.), так и промышленные объекты (химические комбинаты, добыча полезных ископаемых, ледокольный флот и др.). В результате их деятельности на дне этих морей скопилось много радиоактивных отходов, а на суше - промышленных и бытовых отходов. Тем не менее, только в тундре в Ненецком национальном округе сохранились нетронутые естественные ландшафты единственные в Европе.

Из крупных аварий на зарубежном Севере можно отметить следующие. Во-первых, это крушение танкера "Exxon Valdex" на Аляске в 1989 г., которое считается крупнейшей экологической катастрофой на Севере. На компанию был наложен штраф в 4.5 млрд долл. Следствием этой катастрофы стало резкое сокращение популяции рыб. Кроме этого, в 1980-е гг. у побережья Канады и в северной части Северного моря произошли три крупные аварии с затоплением и разрушением нефтедобывающих платформ.

На Аляске современные технологии, применяемые при обустройстве новых месторождений, с одной стороны, уменьшают давление на природу (направленное бурение, обратная закачка буровых отходов в землю и т.д.), с другой стороны - увеличивают нагрузку, так как для сейсмологической разведки в системе 3D применяется более плотная сетка скважин - через 1-1.5 км, а не через 4-5 км как при обычных методах. При этом в 4-5 раз возрастает потребление воды для бурения. Вода также в больших количествах требуется и для создания дорожной сети (так называемые ледяные дороги) - на 10 км идет 25-30 тыс. т воды при ограниченности водных ресурсов в регионе. Наиболее пострадала природа на северном склоне Аляски, где ведется основная нефтедобыча. Здесь к категории "нарушенные земли" относится порядка 10 тыс. га [16].

Для смягчения экологической ситуации в АЗ все более широкое применение находят возобновляемые виды энергии (ГЭС и ВЭС), идет масштабное строительство ЛЭП для снабжения из этих источников военных и гражданских объектов. В последнее десятилетие стал развиваться арктический туризм, что также увеличивает экологическую нагрузку на территорию. Наибольшее давление на природу характерно для северной Швеции, где особенно активна экономическая и туристическая деятельность. Доля нарушенных земель превышает $35 \%$, к 2050 г. она может возрасти до $75 \%$. Активизация экономической и рекреационной деятельности угрожает коренным жителям - саамским оленеводам [13].

Негативные процессы уже привели к сильнейшей трансформации естественного геохимического фона, загрязнению атмосферы, деградации растительного покрова, почвы, внедрению вредных веществ в цепи питания, повышенной заболеваемости населения. Климатические и гидрологические особенности акватории Северного Ледовитого океана способствуют интенсивному осаждению вредных веществ, которые в значительных количествах приносятся из Западной Европы атмосферными массами и Гольфстримом. На загрязнение атмосферы и усиление парникового эффекта оказывают влияние сибирские торфяные болота, возникшие приблизительно 11 тыс. лет назад. Они выделяют метан, который удерживается вечной мерзлотой или откладывается в виде метангидратов. При таянии он попадает в атмосферу. В случае потепления климата метан из сибирских болот может оказать такое же влияние на создание парникового эффекта как 10-25\% углекислого газа, который сегодня выдает в атмосферу вся мировая энергетика.

Одной из главных мировых проблем стало отсутствие технологий ликвидации подледного разлива нефти, так как существующие технологии по сбору нефти при низких температурах не работают. Нефть или нефтепродукты приходится собирать вручную, как это было при аварии в Мурманске в 2009 г. Немалый риск для уязвимой морской среды Арктики может привести активизация движения по СМП, на отдельных участках которого вообще нет каких-либо аварийно-спасательных служб, поэтому любая нештатная ситуация может иметь катастрофические последствия. МЧС России планирует создать систему из 10 специализированных аварийно-спасательных центров. В зону их ответственности войдут приполярные районы, вся трасса СМП и российский сектор Арктики.

Север особенно уязвим и неустойчив к антропогенным воздействиям, каждое нарушение равновесия ведет к последствиям, для устранения которых требуются большие финансовые средства и очень много времени. Для нештатных ситуаций предполагается создать специальный международный финансовый фонд, средства которого будут идти на предупреждение и ликвидацию чрезвычайных ситуаций и их последствий. Россия и Норвегия развивают инфраструктуру контроля и мониторинга окружающей среды, которая в будущем станет общей российско-норвежской системой раннего оповещения и реагирования. 
Для сохранения хрупкой природы Севера в регионе необходимо увеличить число заповедников и охраняемых территорий. Так, Г.А. Агранат и В.М. Котляков считают, что Север прежде всего эколого-географический резерв. На суше осталось лишь $27 \%$ ненарушенных земель, из них $60-70 \%$ приходится на Север. Необходимо увеличить площадь особо охраняемых территорий до $25 \%$ и создать этноэкологические зоны с целью сохранения и обеспечения занятости коренных народов Севера и охраны природной среды их обитания [1].

Охраняемые территории являются важным инструментом для сохранения видов флоры и фауны и их мест обитания. В настоящее время национальные парки в арктической и приарктической зоне занимают около $1 \%$ их общей территории. Под эгидой Арктического совета создается план по охране северных территорий (CPAN) с учетом международных и национальных законодательных норм в отношении охраняемых территорий. Этот план будет способствовать устойчивости экосистем арктической зоны к изменению климата и других компонентов окружающей среды. Он также поможет коренным народам не только сохранить традиционные культуру и быт, но и приспособиться к меняющимся реалиям, сформировать новые отношения, возникающие при промышленном освоении АЗ.

Стратегия охраны окружающей среды была принята в Рованиеми (Финляндия) в 1991 г. Ее главные задачи - мониторинг состояния природы, а также сохранение арктической флоры и фауны, предотвращение и борьба с экологическими чрезвычайными событиями.

Противоречия между странами в перспективном развитии Арктики. Противоречия между странами в вопросе о деятельности в АЗ существуют с XIX в., когда претензии на нее выдвигали государства, чьи экспедиции проводили здесь исследования: Россия, Австро-Венгрия, Швеция, Норвегия, США, Великобритания. Появились проекты раздела Арктики между великими державами по образцу раздела Африки и Азии. Первым международно-правовым актом, фиксирующим северо-восточные границы России в Арктике, была Российско-британская конвенция о разграничении владений двух стран, подписанная в 1825 г. в Санкт-Петербурге.

Ю.Ф. Лукин выделяет три этапа в разделе АЗ, который он называет "Великим переделом Арктики”. Во время первого этапа, продлившегося до середины XX в., в результате односторонних действий юридически были закреплены границы между зонами за каждой арктической страной, имеющей выход в Северный Ледовитый океан, согласно секторальному делению, установленному на Парижской конференции 1920 г. Во время второго этапа, с середины XX в., переговоры о делимитации Арктики велись на международных конференциях, где принимались различные конвенции и соглашения. Особое значение имеют конференции 1958 г. и 1982 г., когда были приняты Конвенция по континентальному шельфу и Конвенция ООН по морскому праву, которую подписали все арктические страны кроме США. В начале XXI в. начался третий этап "Великого передела", на котором речь идет не только о разделе Арктики между арктическими и приарктическими странами, но и о разделе или интернационализации так называемой зоны ООН вокруг Северного полюса [6].

Отдельные страны по поводу делимитации границ придерживаются разных принципов. Вопервых, Россия и Канада считают, что раздел должен проходить по секторам. В основе этого лежат результаты Парижской конференции и Конвенции по морскому праву. Каждой из арктических стран в этом случае отводится “полярный сектор" в виде треугольника, основанием которого служит северная граница страны, вершиной - Cеверный полюс, а боковыми границами - меридианы, соединяющие полюс с крайними точками основания. Границы экономических зон проходят на расстоянии 200 миль от северного побережья каждой страны. Во-вторых, европейские страны, также опираясь на конвенцию 1982 г., прежде всего Дания и Норвегия, считают, что определение границ должно происходить по принципу деления по срединной линии. Акватория делится пропорционально протяженности береговой линии каждой из стран-претендентов на следующие зоны: 1) внутренние воды; 2) территориальные воды; 3) прилежащие воды; 4) исключительная экономическая зона; 5) континентальный шельф; 6) открытое море вне национальных юрисдикций. В этом случае выигрывает Дания, так как Северный полюс оказывается под ее юрисдикцией. В-третьих, США, имеющие самый маленький сектор, предлагают считать национальной зоной только 12-мильную зону вдоль побережья. Циркумполярная территория вокруг полюса отходит под юрисдикцию ООН и становится свободной для всех субъектов международного права. Все транспортные маршруты, включая СМП и Северо-Западный проход, в этом случае становятся интернациональными.

Несогласие арктических стран с существующими разделительными линиями по морским 
пространствам и шельфу ставит перед международным сообществом ряд важным проблем. Пять арктических стран спорят о землях, водах и льдах - что кому и где принадлежит в основном из-за полезных ископаемых и биоресурсов, доступ к которым открывается благодаря глобальному потеплению. Также спорным остается вопрос о принадлежности транспортных коммуникаций. В целом претензии стран выглядят следующим образом.

Россия, имеющая наибольший сектор (5.8 млн кв. км), понесла самые значительные потери при разделе АЗ. Во-первых, после Первой мировой войны при подведении ее итогов на Парижской конференции Россия потеряла Шпицберген и большое число арктических островов общей площадью 63 тыс. кв. км, отошедших к Норвегии. Во-вторых, после ратификации Конвенции 1982 г. СССР добровольно отказался от особых прав на 1.7 млн кв. км в А3, которые вошли в околополюсную зону под юрисдикцией $\mathrm{OOH}$ со статусом общего наследия человечества, где промышленную и транспортную деятельность могут осуществлять любые государства под эгидой ООН [3]. В-третьих, в 1990 г. была пересмотрена граница между Россией и США в Беринговом и Чукотском морях, установленная в 1867 г.

По новому соглашению государственные границы между США и РФ проходят по внешнему пределу территориальных вод приполярных стран - 12-мильной зоны, экономические зоны занимают пространство в 200 миль от национального побережья. В некоторых местах между США и РФ экономические зоны перекрывают друг друга, так как расстояние здесь меньше 400 миль. Поэтому выгоду получает та сторона, у которой есть острова на некотором удалении от берега. В целом же произошло безвозмездное отторжение в пользу США около 60\% примыкающей к океану акватории Берингова моря. Разграничение экономических зон и континентального шельфа в Беринговом проливе проходит между островами Ратманова (РФ) и Крузенштерна (США). По условиям соглашения к США отошли: 1) часть экономической зоны России площадью более 30 тыс. кв. км; 2) участок континентального шельфа площадью 46 тыс. кв. км в центральной части Берингова моря, находящийся за пределами 200-мильной экономической зоны США. Россия по этому соглашению получила 5 тыс. кв. км экономической зоны США [20]. США ратифицировали это соглашение, Россия нет, но и не денонсировала, несмотря на его дискриминационный характер. Это соглашение побудило и другие арктические страны выступить с претензиями к РФ на часть ее арктической зоны. Из приобретений в $\mathrm{XX}$ в. можно отметить лишь район Печенги (Петсамо), до войны принадлежащий Финляндии, который СССР получил по итогам Второй мировой войны.

России необходимо удерживать и укреплять свои позиции в АЗ, поскольку Север - это стратегический район по целому ряду причин: 1) относительно дешевые поставки сырья и энергоресурсов; 2) после распада СССР возросло значение северных портов и транспортных магистралей; 3) АЗ - экологический и территориальный резерв мирового масштаба; 4) геополитическое положение и глобализация усилили роль северных регионов в мировом хозяйстве; 5) важен фактор и военного присутствия, так как арктическое побережье является государственной границей нашей страны; 6) России принадлежит ведущая роль в мире в изучении и освоении Арктики (станции “Северный полюс" и др., СМП, мощный ледокольный флот, полярная авиация, промышленные предприятия, военные базы и др.)

И.М. Могилевкин из ИМЭМО РАН считает Север тыловым районом для всей России, особенно для Сибири и Дальнего Востока. Политические и территориальные проблемы, возникающие на южных рубежах, можно будет смягчить или даже удастся их избежать в значительной мере, если северные территории возьмут на себя транспортные проблемы тех субъектов РФ, которые не имеют прямого выхода на внешние рынки. Этому способствует гидрографическая сеть, так как крупные реки Сибири впадают в Северный Ледовитый океан. Если задействовать этот транспортный ресурс в полной мере, то многие регионы нашей страны обретут большую свободу для пространственного маневрирования, поскольку из АЗ Россия имеет выход как в Атлантический, так и Тихий океан [7].

Для укрепления своих позиций в Арктике Россия не должна рассматривать Север только с позиций военно-стратегических интересов, как это было в советское время, когда была создана высокозатратная модель, не отвечающая современным реалиям. По мнению А.Н. Пилясова, новая стратегия должна опираться на экономику знаний, т.е. инновационную экономику, что позволит перебороть негативное воздействие транспортной удаленности и высоких издержек [9].

Стратегической задачей на ближайшее время стало уточнение границ шельфа и линий разграничений экономических зон. Если с разграничением экономических зон вопросы решаются путем переговоров, то для определения границ 
шельфа необходимы дополнительные научные изыскания, которые проводятся всеми арктическими государствами. Россия первой из них подала заявку в ООН в 2001 г. на признание хребтов Менделеева и Ломоносова продолжением ее континентального шельфа. Удовлетворение этой заявки позволило бы увеличить российский сектор на 1.2 млн кв. км. Заявка была отвергнута. В 2007 г. для подтверждения своих прав был установлен на дне под Северным полюсом российский флаг, что вызвало резко негативную реакцию со стороны других стран, которые также претендуют на эти хребты и поднятия. Так, Дания считает, что хребет Ломоносова - это затонувшая часть Гренландии. Канада также претендует на этот хребет, поскольку он тянется от российских Новосибирских островов до канадского о. Элсмир через Северный полюс. Американцы утверждают, что хребет Ломоносова структурно изолирован от материковой окраины РФ.

Следующую заявку Россия предполагает подать в ООН в 2014 г., где права на шельф будут обосновываться на основании геологической истории АЗ, подтвержденной геолого-геофизическими данными [5]. Решению этой проблемы будут также способствовать двусторонние переговоры с США, Данией и Канадой.

Канада, которой принадлежит 1.4 млн кв. км A3, приняла "Генеральную программу канадской политики в Арктике и на крайнем Севере”. Министр природных ресурсов Канады Гэри Лунк заявил, что "необходимость утвердить суверенитет в Арктике никогда не была столь важной для Канады, поэтому исследованием континентального шельфа был присвоен высший приоритет" [цит. по 6]. Как и РФ, Канада ведет исследования для обоснования своей заявки в $\mathrm{OOH}$ о принадлежности хребта Ломоносова. Она также имеет претензии к Дании относительно о. Ханс, контролирующего Северо-Западный проход, а также она объявила своей собственностью все земли к западу от Гренландии между Канадой и Северным полюсом.

Позиции Канады и РФ во многом схожи, так как если будет принят принцип раздела по срединной линии, то обе страны потеряют права на СМП и Северо-Западный проход, поскольку они окажутся за пределами их территориальных вод (12-мильной зоны). Преобразование этого маршрута в международный лишит РФ и Канаду прав на регулирование судоходства, что скажется прежде всего в финансовой сфере. Это отражается в лозунге, выдвинутом канадским правительством - “либо используем Арктику, либо ее по- теряем”. Разногласия существуют в основном по хребту Ломоносова. Для решения этого вопроса нужен прежде всего двусторонний диалог, а не в рамках пяти арктических стран. Свои претензии и предложения по разделу Арктики Канада представит в ООН в 2013 г.

Особых успехов в расширении своей АЗ добилась Норвегия, увеличив ее площадь с конца $\mathrm{XX}$ в. с 0.7 до 1.1 млн кв. км после переговоров и одобрения их Комиссией ООН по шельфам с Россией с использованием "soft power". Заключение договора с РФ стало окончанием противостояния двух стран, длившегося почти 40 лет. Обе страны в одностороннем порядке заявляли о своих правах на шельф и акваторию, что противоречило Парижскому договору. РФ пошла на заключение договора, чтобы исключить очаг нестабильности, где часто возникали непредвиденные ситуации, для решения которых могла быть привлечена НАТО, что еще больше бы накалило обстановку. Договор был подписан в 2010 г., в результате чего к Норвегии отошел Свод Федынского, в несколько раз по своим потенциальным запасам углеводородов превосходящий Штокмановское месторождение. Он стал очень выгоден Норвегии, так как ресурсы Арктики должны прийти на смену истощающимся ресурсам Северного моря - основы благосостояния и процветания государства.

Освоение североморских месторождений с тяжелыми условиями добычи в труднодоступных районах позволило Норвегии создать уникальные технологии, которые будут востребованы при перемещении добычи нефти и газа из Северного моря в Баренцево. Россия очень заинтересована как в этих технологиях, так и в сотрудничестве с норвежскими компаниями. Первый крупный арктический проект РФ - Штокмановское месторождение - находится вблизи новой границы, вплотную примыкает к так называемой бывшей “серой зоне", которая вошла в состав Норвегии и где возможно открытие новых углеводородных месторождений. Обе страны имеют планы по объединению этих месторождений для создания единого газового мегаполиса с общей инфраструктурой.

Норвегия имеет наибольшее число территриальных претензий к соседям. Участок спорной территории в Баренцевом море представляет собой шельф размером 175 кв. км, включая перекрывающие друг друга исключительные экономические зоны соседних государств. Несмотря на подписание договора о новой границе, между Россией и Норвегией остались разногласия по статусу СМП, который Норвегия не считает 
национальным достоянием РФ, и по вопросам рыболовства в зоне Шпицбергена, из-за чего российские рыболовные компании могут лишиться крупных районов рыболовного промысла. Король Норвегии издал “Декрет о Шпицбергене”, сделав район вокруг него своей экономической зоной, введя тем самым ограничения на ведение промысла там другим странам. Камнем преткновения может стать и Земля Франца-Иосифа, на которую Норвегия предъявляла права в начале 1990-х гг.

Дания, которая благодаря Гренландии имеет 0.3 млн кв. км А3, утверждает, что Северный полюс должен принадлежать ей, поскольку он связан с островом подводным хребтом Ломоносова. В самой же Дании есть разногласия с политикой входящей в ее состав Гренландии в отношении статуса этой самоуправляющейся территории, претендующей на получение "широкой” политической и экономической автономии. В настоящее время Гренландия получила право самостоятельно распоряжаться полезными ископаемыми острова и примыкающей к нему 200-мильной экономической зоны. Получение широкой автономии Гренландией может сказаться на расстановке политических сил в регионе, так как не исключено, что аналогичный статус захотят получить Фарерские о-ва (еще одна самоуправляющаяся территории в Дании), вблизи которых находятся месторождения нефти и газа, и принадлежащий Норвегии Шпицберген с его крупными запасами угля и биологических ресурсов.

После покупки Аляски США стали арктической страной, обладающей 0.1 млн кв. км А3. США объявили Арктику зоной своих стратегических интересов. Был принят “Арктический план действий США”, где определена стратегия США в Арктике. Они имеют претензии к РФ по границе в Беринговом море, о чем было сказано выше, к Канаде - по Северо-Западному проходу и спорным участкам моря Бофорта, к Канаде и Дании из-за их притязаний на Северный полюс. Они оставляют за собой право действовать в одностороннем порядке и осуществлять контроль за АЗ за пределами демаркационных линий. США определяют свои политико-экономические интересы как расширение своего экономического присутствия при одновременной демонстрации своего морского могущества. По словам командующего службой береговой охраны США адмирала Тэда Алена "стратегические интересы США в Арктике расширяются как внутри страны, так и в международном масштабе” [6]. США не подписали Конвенцию ООН по морскому праву, поэтому они более свободны в формировании своей арктической политики, имеющей в какой-то мере двой- ственный характер. С одной стороны, они хотят ослабить свою зависимость от стран Ближнего Востока в поставках углеводородов, с другой стороны, переориентируясь на поставки из Арктики, они заинтересованы в увеличении доли Норвегии и России в своем импорте, опасаясь при этом зависимости от России.

Кроме арктических стран конкретные притязания в Арктике имеет Великобритания, считая своей скалу Роколл, на которую претендуют Дания, Ирландия и Исландия. Причиной британских притязаний на этот остров в северной Атлантике площадью 570 кв. км, не пригодной для жизни из-за отсутствия здесь пресной воды, стали недавно найденные крупные запасы нефти, а также обилие морепродуктов в прибрежных водах.

Для упрочения своих позиций в Арктике США ставят во главу угла учет, прежде всего, экологических факторов и добиваются интернационализации Северного Ледовитого океана, что приведет к исчезновению деления его акватории на национальные сектора. Все страны мира будут равны при таком раскладе в освоении ресурсов Арктики. Такое мнение разделяет прежде всего Китай, всеми способами пытающийся закрепиться в А3, где он проводит научные исследования (создание своей научной станции на Шпицбергене), изучает возможности прохода по СМП своими силами (в качестве примера приведем экспедиции по нему китайского ледокола “Снежный дракон”), пытается приобрести 300 кв. км островной территории Исландии с целью создания своего форпоста на пути из Европы в Китай через СМП, сотрудничает с РФ, заключив рамочное соглашение с правительством Мурманской области о совместной работе по обеспечению работы мурманского порта и СМП. Япония и Индия, опираясь на свои финансовые возможности, также разрабатывают планы практической работы в Арктике.

Помимо экологических проблем существует и проблема милитаризации Арктики на современном уровне развития военной техники и стратегии. Хотя противостояние здесь носит в основном политический характер, все чаще появляются данные о военных планах арктических государств, направленных на обеспечение своей безопасности и стабильности в регионе, который ранее был объявлен безъядерной зоной. Конфликты на разных уровнях, особенно в области делимитации границ, усиливают нестабильность. Из-за этого Арктику иногда называют "регионом анархии".

Арктические страны уделяют этой теме большое внимание. Россия модернизирует свои пограничные заставы, центры космического слежения 
и т.П. На Севере дислоцируются оборонные объекты различного назначения. В случае роста напряженности в А3, по мнению ряда политиков, в частности президента Академии геополитических проблем Л.Г. Ивашова, РФ должна увеличить свое военное присутствие. От Кольского полуострова до Чукотки расположены системы предупреждения о ракетном нападении и ракетно-зенитные дивизионы. Для усиления военного присутствия идет модернизация российского ВМФ, закладываются и строятся новые надводные корабли и подлодки, наиболее эффективные при плавании в северных широтах [18].

Арктика для США является важным стратегическим регионом, так как на Аляске располагается инфраструктура системы НОРАД, прикрывающая США и Канаду с севера, а также наземные и морские средства для переброски вооруженных сил в Арктике в случае военных конфликтов. В связи с таянием льдов Северный Ледовитый океан стал важным стратегическим направлением для ВМФ США, в том числе и атомных подводных лодок. Свои военные базы и аэродромы США имеют не только на своей территории, но и в Канаде на побережье Гудзонова залива, в Гренландии и Исландии, а в Норвегии и Канаде находятся компоненты противолодочных систем. США не собираются увеличивать число своих военных баз, они делают упор на свой ВМФ - крупнейший в мире. Американские авианосные группировки могут создать довольно быстро ощутимое присутствие в любой точке земного шара.

Канада, не имеющая ни мощного МВФ (всего 33 корабля, из которых 4 - подводные лодки), ни значительных сухопутных сил, для усиления своего военного присутствия планирует закупить партию беспилотных летательных аппаратов для мониторинга действий флотов РФ и США. Также она строит до 6-8 патрульных кораблей и возводит новый порт на северной стороне Баффиновой Земли. Все это делается в основном для обеспечения контроля над Северо-Западным проходом. Канада уже объявила об обязательной регистрации в канадской береговой охране всех судов, заходящих в эти воды.

Несмотря на планы по усилению военного присутствия каждой из арктических стран, между ними развивается военное сотрудничество на разных уровнях - проводятся совместные учения и консультации. Так, в апреле 2012 г. в Канаде состоялась встреча начальников генеральных штабов и высших армейских чинов из России, Канады, США, Дании, Финляндии, Исландии, Швеции и Норвегии. Такие встречи дают надеж- ду, что эскалация военного присутствия в регионе не примет значительных масштабов, несмотря на скрытую конфронтацию, в основе которой лежат противоречия между внутренними национальными интересами и проблемами интернационализации региона. Есть надежда, что военное противостояние не станет решающим фактором в борьбе за арктические ресурсы, прежде всего энергетические.

Борьба за расширение своих владений в Арктике в настоящее время не очень актуальна, поскольку уже открытые энергетические ресурсы, как правило, находятся в 200-мильных экономических зонах каждой страны. Их доля достигает 90-95\% от гипотетических энергоресурсов Арктики. Освоение еще не открытых месторождений за пределами этих зон - вопрос далекого будущего при сохранении тенденции потепления климата в регионе и разработке новых технологий для глубоководных ГРР в районах Северного Ледовитого океана, где глубины достигают 4 тыс. м.

Разработка шельфовых месторождений в А3 имеет очень высокие производственные издержки. Для этого потребуется кооперация между частными и национальными компаниями не только арктических стран, но и тех государств, которые заинтересованы в увеличении поставок энергоресурсов за счет стран-экспортеров.

Сейчас на мировом рынке энергии наблюдается положение равновесия между спросом и предложением. Потребление энергии после восстановления темпов роста в мировой экономике будет расти, большой вклад в этот процесс внесут страны с переходной экономикой и развивающиеся страны, часто удовлетворяющие свои растущие потребности за счет импорта. В то же время усиливается тенденция на удовлетворение внутреннего спроса за счет собственных, как традиционных, так и нетрадиционных и альтернативных источников энергии для повышения уровня национальной энергетической безопасности. Эта проблема решается достаточно успешно во многих странах за счет форсированного развития собственной энергетической базы.

Активные ГГР во многих регионах мира привели к открытию новых месторождений углеводородных ресурсов, причем в основном в местах, имеющих более благоприятные природные условия для разработки таких месторождений по сравнению с месторождениями арктического шельфа.

Финансовый кризис и вызванные им трудности (жизнеспособность зоны евро, сбои в налоговобюджетной политике США и др.) также не спо- 
собствуют притоку инвестиций в арктические проекты. Директор-распорядитель МВФ К. Лагард считает главным приоритетом на сегодняшний день преодоление текущего кризиса и восстановление экономического роста для создания новых рабочих мест.

Хотя между арктическими странами нет полного взаимопонимания по вопросам разграничения, наиболее вероятным в определении и закреплении национальных границ континентального шельфа и экономических зон будет сценарий, основанный как на научно подтвержденной информации, так и на существующих международных правовых нормах. Вероятнее всего будет найдено компромиссное решение с подписанием соответствующего документа, в котором будет предусмотрена возможность разрешения территориальных и/или иных споров путем переговоров и заключения двусторонних соглашений.

Для разрешения существующих противоречий у арктических стран есть еще 10 лет, когда они смогут подтвердить или расширить свою зону, если сумеют доказать, что та подводная площадь, на которую они претендуют, в геологическом плане является частью ее континентального шель$ф а$, то есть продолжением ее собственной территории. Если же в обозримой перспективе они не смогут собрать достаточно данных для подтверждения своих претензий, то тогда решение Комиссии ООН может быть отложено на время, необходимое для сбора данных независимыми международными экспертами.

\section{СПИСОК ЛИТЕРАТУРЫ}

1. Агранат Г.А., Котляков В.М. Российский Север край больших возможностей // Вестник РАН. 1999. № 1. C. 3.

2. Бартош А. Арктика в прицеле НАТО // Военнопромышленный курьер. 2009. № 6(272).
3. Гудеев П.А. Россия в Арктике // www.regnum.ru. 21.01.2013.

4. Кутузова М. Юбилей на шельфе // Нефть России. 2011. № 11. С. 66-67.

5. Лаверов Н.П., Кононов М.В. и др. Базовая модель тектонического развития Арктики как основа для подготовки обновленной заявки России в Комиссию ООН на установление внешней границы континентального шельфа // Арктика: экология и экономика. 2012. № 2. С. 4-19.

6. Лукин Ю.Ф. Российская Арктика в изменяющемся мире. Архангельск, 2012. 482 с.

7. Могилевкин И.М. Новый взгляд на мировую экономику и общественное развитие. М.; СПб.: НесторИстория, 2012. 237 с.

8. Нефть России. 2012. № 3. С. 43.

9. Пилясов А.Н. И последние станут первыми: Северная периферия на пути к экономике знаний. М.: Либроконь, 2009. 544 с.

10. Рукша В.В., Смирнов А.А. и др. Арктический регион и атомный ледокольный флот России // Арктика: экология и экономика. 2012. № 1(5). С. 8.

11. Arctic Development and Maritim Transportation. Island, 2007.

12. Arctic Development. Nawara-Program. 2007. P. 22.

13. Development in the Arctic: EC opportunities, Environment and Cultural Challenges // www.unep.org. 2010.

14. Lindholt $L$. Arctic National Resources in Global Perspective // The Economy of the North. 2005. P. 2732.

15. Nord-News // Информационное агентство. 22.08. 2012.

16. Potential Impact of Proposed Oil and Gas Development of the Arctic Refuje"s Coastal Plan: Istorical Overwiew and Issues of Concern // US. Fish and Wildlife Service. 2001. P. 1-3.

17. Tiksi Science Plan - Tiksi International Hydro-Meteorological Observatory // Int. Arctic Syst. Atmosphere. 2011. P. 8-11.

18. www.arctictoday.ru. 30.03.2012.

19. www.regnum.ru. 29.01.2012.

\title{
Geopolitical Problems of the Arctic
}

\author{
T. I. Gorkina \\ Institute of Geography, RAN
}

The problems of international cooperation and competition of the Arctic countries in the delimitation of the borders and the future using of the Arctic region are examined. 